\title{
Ways to Strengthen the Effectiveness of Moral Education Courses in Colleges and Universities
}

\author{
Minghui Chen ${ }^{1, *}$
}

\author{
${ }^{1}$ Yunnan Normal University, Kunming, Yunnan 650000, China \\ *Corresponding author. Email:893563012@qq.com
}

\begin{abstract}
Moral education occupies the primary position in the quality-oriented education system of colleges and universities, and is also an important way to promote the overall development of students' comprehensive quality. In the new era, it is suggested to establish a standardized teaching mechanism in the curriculum construction, create an open curriculum system, build a high-quality teaching team, realize diversification and modernization of teaching methods, set a reasonable evaluation system, and form a long-term working mechanism of continuous improvement and innovation, so as to enhance the effectiveness of moral education courses in colleges and universities.
\end{abstract}

Keywords: Moral education, College students, Comprehensive quality education.

\section{INTRODUCTION}

With the development of higher education, improving the comprehensive quality of college students has become an important content of the university education and training, and is also an important goal of future education and teaching reform. The strategic theme of "National Medium and Long-term Educational Reform and Development Planning Outline (2010-2020)" is to adhere to moral education first, adhere to ability, and adhere to all-round development. [1] As the core of quality-oriented education in schools, moral education refers to the education of students' ideology, politics, morality, law and mental health. At the same time, it is an important part of school education, which is interrelated, infiltrated and closely coordinated with intellectual education, physical education, aesthetic education and labor education, and also plays an important role in guiding, driving and ensuring the healthy growth of students and school work. Colleges and universities should focus on the goal of talent training, actively explore effective ways of moral education, constantly deepen education and teaching reform, strive to expand education and teaching channels, establish a long-term mechanism of moral education course, and realize the educational goal of all-round development of college students.

\section{IMPROVING THE TRAINING PLAN AND GRASPING THE CORRECT EDUCATIONAL ORIENTATION}

The objectives and contents of moral education in colleges and universities should reflect comprehensiveness, guidance, timeliness and pertinence. The comprehensiveness is mainly reflected in the rich contents. The course contents should cover national spirit, ideals and beliefs, moral quality, code of conduct, mental health education, etc., which meets the requirements of college students' theoretical knowledge development and ability training. Guidance includes political guidance, theoretical guidance, value guidance and psychological guidance. In terms of political guidance, it is suggested to cultivate students' firm and correct political direction and position; in terms of theoretical guidance, it is necessary to cultivate college students' scientific views and methods of understanding and transforming the world; in terms of value guidance, it is required to correctly handle the relationship between man and nature, between man and society, and among human beings, and establish the life value goal of serving the people; in terms of psychological guidance, it is better to help college students solve their confused problems 
from the level of behavior norms and behavior mediation, and improve their ability of psychological and behavior regulation and civilization. According to timeliness requirement, curriculum education must keep up with changes in the times and the situation. And then, college students can grasp the mainstream and overall situation of today's world and agree with the principles and policies of the party and the government. According to the pertinence requirement, the curriculum education should be aimed at the ideological quality, psychological characteristics and mental outlook of college students, and the focus, hot spots and difficult problems affecting young students should be analyzed. Then, colleges can guide students to understand the current situation and policies comprehensively and correctly, cultivate their ability to think and solve problems independently, standardize their practical behavior, and help students establish healthy psychological quality and sound and good personal quality. Therefore, the requirements of the state for the cultivation of moral education of talents will be realized, and the function of overall-quality cultivation of college students will be achieved.

\section{CONSTRUCTING THE CURRICULUM SYSTEM AND FORMING A COMPREHENSIVE KNOWLEDGE STRUCTURE}

The core of university education is curriculum education. And moral education should first reflect its advantages in curriculum setting, and break the past single and closed curriculum system in curriculum construction, achieving the changes from the less to more in quantity, from the shallow to the deep in quality, and from the scattered to the overall in structure, and forming an open and organic education curriculum system. Then, colleges can really help students to expand multidisciplinary knowledge, expand multidimensional vision, and cultivate multi-angle thinking mode, so as to enhance students' comprehensive quality of compatible arts and sciences.

In general, the contents of moral education courses include national spirit education, ideal and belief education, moral quality, civilized behavior education, discipline and law-abiding education, mental health education, etc. National spirit education enables college students to understand the current international and domestic situation, major world events and the government's principled position, and college students' sense of social responsibility and national pride will be strengthened. From the perspective of national mission, national responsibility and people's expectations, colleges guide young college students to pursue lofty ideals, firm lofty beliefs and take the great cause of national rejuvenation as their own responsibility with ideal and belief education. Through moral quality and civilized behavior education, college students are guided to abide by social morality and professional ethics, carry forward family virtues, temper personal morality and standardize their behaviors in practice. At the same time, with the guidance of discipline and lawabiding education, it is necessary to conduct basic legal knowledge education for college students, help college students improve their awareness of the rule of law, and improve their quality of the rule of law. Then, college students can become the models of respecting, abiding by and using the law. In terms of mental health education, colleges mainly carry out the education of basic knowledge of mental health and psychological consultation, counseling and assistance, help students improve their psychological functions, cultivate good psychological qualities, shape a sound personality, give college students psychological counseling and spiritual comfort, and guide college students to enhance their ability to withstand setbacks and adapt to the environment.

\section{STRENGTHENING THE CONSTRUCTION OF TEACHERS AND IMPROVING THE QUALITY OF QUALITY-ORIENTED EDUCATION}

"Teachers are the guides and leads for the moral education of normal students in colleges and universities." [2] China should "prioritize the development of education, fully implement the party's education policy, implement the fundamental task of cultivating morality, and emphasizing the strengthening of teacher ethics and ethics, build and train a team of high-quality teachers, and advocate the whole society to respect teachers and education."[3] The key to moral education lies in teachers. Teachers should not only have high professional level, but also have good intellectual equipment, and also have strong awareness, methods and ability to analyze and solve problems. By taking measures such as internal training and external introduction, it is 
suggested to optimize the knowledge structure, professional title structure, educational background structure and age structure of teachers, improve the overall quality and professional level of teachers, and encourage teachers to continuously improve teaching quality.

Colleges and universities should attach great importance to the construction of teachers, effectively integrate resources, carefully select teachers with high academic level and excellent professional ethics, and form a moral education team to realize the "Four Combinations", namely, the combination of experts inside and outside the school, the combination of full-time and part-time teachers, the combination of student management teachers and front-line teaching teachers, and the combination of multi-disciplinary teachers and researchers. In addition, colleges and universities shall invite relevant experts and scholars to join the teaching team, cultivate teaching and scientific research innovation team and high-quality curriculum teaching team, realize the synchronous development of teaching level and scientific research level, and achieve the sustainability of curriculum construction and development. At the same time, colleges should formulate training plans for young teachers, select excellent teachers to go out for further study and improve their professional ability, strengthen teaching exchanges among teachers and give full play to the role of experts, scholars and senior teachers. Also, it is necessary to encourage young teachers to actively apply for various scientific research projects or construction projects, pay attention to teachers' practical training, and make use of teachers' social practice platform to enable teachers to step off the podium, enter life, and go to society and approach students.

\section{USING INFORMATION TECHNOLOGY AND REALIZING THE MODERNIZATION OF TEACHING METHODS}

Moral education should make full use of the conditions provided by modern information technology, reform the teaching content, teaching mode and teaching means, strengthen multimedia teaching and audio-visual teaching, and gradually move towards the modernization of teaching methods and teaching means. Among them, network teaching is a powerful supplement to classroom teaching. Students can conduct online self-study through the three-dimensional teaching resources of campus network, and expand learning time and space, so as to supplement classroom teaching with network auxiliary learning, and realize the integrity of curriculum knowledge and theoretical system.

Colleges should make full use of the network conditions, improve the teaching environment, establish a teaching website for high-quality courses of moral education, upload the collected teaching materials, such as classic cases, courseware and teaching demonstration video materials, to the Internet for students to study online, set up an interactive column between teachers and students on the course website, expand students' learning space through consultation and Q\&A, and enhance the effect of "teaching and learning". Through modern educational technology, colleges can comprehensively improve the effect of network teaching and enhance the advantages of information interaction and resource sharing in the network. At the same time, colleges should build a network platform that can realize interconnection inside and outside the college, interaction between teachers and students and resource sharing, strengthen communication with relevant social departments and institutions, establish an offcampus expert team, realize the integration of personnel from multiple disciplines, multiple fields and multiple departments, and provide intellectual support for all-round and high-quality teaching activities.

\section{FOCUSING ON THE CULTIVATION OF PRACTICAL ABILITY AND PRACTICING THE TEACHING EFFECT}

General Secretary Xi Jinping emphasized on "closely integrating correct moral cognition, conscious moral development, and active moral practice". [4] Young students "must do things, unite knowledge and practice, and be doers" [5] Practical teaching is an important means to cultivate students' analysis ability and innovation ability, and provides students with the opportunity to understand social life and integrate theory with practice. Moral education must follow the law of education and practice, and organize, construct and manage practical education scientifically and effectively.

Practical education should follow the principles of combining educational purpose and students' needs, theoretical education and social practice, educational guidance and care for students, so as to enhance the effectiveness of moral education course with students' social practice. Moral 
education practice base is an important carrier of moral education in colleges and universities. It is necessary to integrate social moral education resources, build moral education practice base in campus, expand the time and space of students' social practice and extracurricular activities, give full play to the moral education role of social organizations, and create a large curriculum environment of moral education. Through school associations, youth volunteer activities and campus special activities, the majority of young students can contact and understand the society, and learn to use Marxist world outlook and methodology to think and solve problems in practice. At the same time, it is necessary to constantly innovate the form of social practice under the guidance of moral education course. Taking the situation and policy course in moral education as an example, a leading organization for students' social practice activities is established every year with the situation and policy teaching and research office as the core and the situation and policy education as the theme; a team of tutors for students' social practice activities is built with teachers in the teaching and research office as the backbone and experts inside and outside the school as the instructors; a group of student social practice volunteers is trained; a group of social practice teams of students is selected; and a key school service team for social practice is established. For each student's social practice, each service team and each student volunteer shall carry out a publicity and investigation of the situation and policies entering the community and the grass-roots level, and complete a social investigation report with the theme of situation and policies, perform a high-quality literary and artistic program to publicize the situation and policies. After the social practice every year, it is necessary to hold a summary meeting of social practice activities with the theme of situation and policy. In addition, when freshmen enter the college, it is required to hold a report meeting on the social practice of student volunteers to form a "ten ones" social practice activity system, so as to further broaden students' vision, enhance their national consciousness, improve their social adaptability and competitiveness, and improve their comprehensive quality.

\section{REFORMING THE EXAMINATION METHODS AND PAYING ATTENTION TO EDUCATIONAL EVALUATION}

College is the stage for implementing qualityoriented education, and a reasonable assessment method is the basis and guarantee for maintaining the operation of the stage. Therefore, an assessment system in line with the requirements of qualityoriented education should be constructed. The assessment system should maximize the subjective initiative of teachers and students, give full play to teachers' teaching creativity and students' learning autonomy, produce the best teaching effect and effectively improve students' comprehensive quality.

In terms of the content of moral education evaluation, it is necessary to fully understand and master the materials that can reflect the moral quality of students to ensure the comprehensiveness and accuracy of moral education evaluation; moral education evaluation methods must be able to reflect students' moral level objectively and impartially; moral education evaluation results must be targeted to improve the actual effect of moral education evaluation. [6] And diversified evaluation methods are adopted in moral course. In addition to the theoretical examination, it also brings the students' practical effect into the students' comprehensive evaluation system. According to the theory of each topic and the characteristics of teaching methods, the examination is carried out by means of papers, online tests, investigation reports, social practice and so on. And there are relevant exercises or papers around the theme in each module. Students should finish them after class and submit online. Also, it is suggested to set up interactive columns between teachers and students, expand students' learning space through consultation and Q\&A, and improve students' ability to think independently and explore problems in depth. At the same time, it is required to cultivate students' ability to pay attention to society and participate in social practice, bring the practical effect into the scope of assessment, and fully mobilize students' initiative and creativity in guiding practice with theory. Finally, colleges should establish a student evaluation mechanism to effectively improve students' learning efficiency and teachers' teaching quality. Through these assessment methods, teachers can evaluate students' learning attitude and learning effect comprehensively, objectively and 
dynamically, and improve the teaching effectiveness of the course.

\section{CONCLUSION}

Moral education course is a systematic project, which involves many important problems, such as the transformation of educational concept, the adjustment of educational system, the construction of teachers, and the establishment of evaluation mechanism. Colleges and universities should actively explore new ways and countermeasures of moral education course, enhance the effectiveness of curriculum education, and realize the organic unity of teaching objectives and educational effects being in line with the practical requirements of the party and the state and meeting the internal needs of college students.

\section{AUTHORS' CONTRIBUTIONS}

This paper is independently completed by Minghui Chen.

\section{REFERENCES}

[1] Wang Yinhua, Yuan Pu, Research on Moral Education Cultivation Strategies of College Students with the Fundamental Task of "Leading Morality and Cultivating People" [J]. Course Education Research, 2015 (05). (in Chinese)

[2] Wang Bing, Li Zhengbang, A Brief Talk on Moral Education of Normal Students from the Perspective of Teachers' Professional Characteristics and Moral Accomplishment [J]. Journal of Hubei Adult Education Institute, 2009 (04). (in Chinese)

[3] $\mathrm{Xi}$ Jinping. "Secure a decisive victory in building a moderately prosperous society in all respects, and strive for the great success of socialism with Chinese characteristics for a new era - a report at the 19th National Congress of the Communist Party of China" [N]. Xinhuanet, 2017-10-28. (in Chinese)

[4] Compiled by the Literature Research Office of the Central Committee of the Communist Party of China. Excerpts from Xi Jinping's Excerpts on Youth and the Work of the Communist Youth League [M]. Beijing: Central Party Literature Press, 2017. (in Chinese)
[5] Xi Jinping, Speech at the Teacher-Student Symposium of Peking University [N]. People's Daily, 2018-05-03 (02). (in Chinese)

[6] Yu Song, Reflection on the Evaluation of School Moral Education from the Perspective of Big Data [D]. Jinhua: Zhejiang Normal University, 2016. (in Chinese) 